\title{
An Investigation into Ancient Greco-Indian Medical Exchanges: Sostratus vs Suśruta
}

\author{
Vijaya Jayant Deshpande*
}

(Received 22 May 2017; revised 03 February 2019)

\begin{abstract}
Greco-Indian contacts which go back to the sixth century BCE became intensified after Alexander's Asian conquest. There are similarities between the description of surgical procedures in famous Greek and Indian works. Whether ancient Greek and Indian medicine and especially surgery were interdependent in their development is a long-standing problem. First/second century CE Roman authors viz. Celsus, Soranus and Galen allude to a surgeon named Sostratus. Sostratus' period is close to that of Suśruta, so is his surgical expertise as alluded to by ancient authors. The names 'Sostratus' and 'Suśruta' are phonetically similar. Therefore, several possibilities come up. Either they were different persons and developed their comparable methods independent of each other, or Sostratus's innovations were incorporated by the Indians under Suśruta's name, or vice versa. In any case it is an interesting topic that needs further research.
\end{abstract}

Key words: Ancient India, Celsus, Galen, Greece, Medical exchanges, Soranus, Sostratus, Suśruta.

\section{INTRODUCTION}

Greeks had contacts with Indians in the sixth century BCE. Although there is no concrete evidence of medical exchanges at that early date, some parallel concepts in ancient Indian and Greek medicine and loan words used in scientific terminology indicate a possibility. Theory of six essences (rasās) and three humors (doșas) of ancient Indian medicine could be compared with the humoral theory of the Greeks. Materia Medica of Dioscorides, compiled in the first century CE, included names of Indian medicinal plants like pippalī, śrnigavera and vacā. Moreover, Greek terms for rice, ginger and pepper have their origin in respective Tamil words (Charlesworth, 1926, p.70). Scholars like John Gilmore (1888, p. 56), H R Zimmer (1948), Julius Jolly (1977), David Bellamy (Bellamy and Pfister, 1992) have discussed them at length. The major event that led to closer contacts between ancient India and Greece was Alexander's (356-312 BCE) Asian conquest. His scientific staff, including physicians, had accompanied him during this time. Asian conquest was followed by the Greek rule in the Northwestern part of the Indian subcontinent. Greco-Indian exchanges became intensified after this event. According to some scholars Indian medical classics were translated into Greek by 300 BCE (Sukh Dev, 1997, p.915). If indeed they were, the translations are no more extant, neither are they mentioned in any later sources. Scholars have also been aware of similarities between the description of certain procedures recorded in ancient Greek and Indian medicine e.g. cataract surgery, extraction of dead fetus, lithotomy etc. for some time now (Jolly, 1977, p.23). More recently, G J Meulenbeld has noted down many parallels between Suśruta-saṃitā and Celsus's De Medicina (Meulenbeld, 1999, pp. 386, 327, 328,

*76/37 A, Erandawana, Pune-411004, Email: vijaya.deshpande@gmail.com. 
332, 382, 382, 387, 412, 413). ${ }^{1}$ He pointed at similarities in surgical treatments of growths, eye diseases, rhinoplasty, fractures, dislocations, and extraction of teeth.

To resolve the question whether ancient Greek and Indian medicine and especially surgery were interdependent in their development, it will be useful to analyze certain instances in depth. In this article we examine selected paragraphs from the works of first/second century CE Roman authors, viz. Celsus, Soranus and Galen. They are those which allude to a surgeon named Sostratus (written as Sostratos in Greek). Sostratus' period is close to that of Suśruta, the famous medical personality of ancient India. We find surgical expertise attributed to Sostratus comparable to Suśruta's as seen in Suśruta-samhitā. Also Suśruta's name is phonetically akin to Sostratus.

In the past, searching into the roots of certain names and words led scholars to astonishing facts that helped in ironing out history. It was a pathbreaking discovery by William Jones when he identified Sandracottus, mentioned by Megasthenes (Jain, 1972, pp. 5, 45; Majumdar, $1960)^{2}$ the Greek ambassador sent to India by Seleucus Nicator, as Chandragupta the ruler of
Pătliputra which is modern Patna. Later an alternative spelling of Sandracottus as Sandrakuptos was discovered and it not only fixed the identity of Sandracottus but the chronology of ancient Indian history too. According to Megasthenes, Sandracottus had defeated Seleucus. Seleucus is known to have returned to Babylon in 312 BCE. Again the date of Alexander's visit is known as 325 BCE. Candragupta had not yet ascended the throne by then. Thus, Candragupta's ascending the throne was fixed between 325-312 BCE and thereby the dates back to Buddha's birth were decided using Sanskrit kings' lists. In this way, phonetic similarity of Sandracottus and Candragupta, when investigated, led to reducing uncertainties in Indian history by placing it in a solid chronological perspective (Keay, 1989, p. $36)^{3}$

\section{Sostratus and Suśruta}

Suśruta was the famous writer of Suśrutasaṃhita (referred hereafter as SS) (Sastri, 1953), an ancient Indian work on medicine and especially surgery. ${ }^{4}$ As the story goes, after learning the techniques from Dhanvantarī, Suśruta wrote the earliest version of $S S$ and it is given an approximate date of a few centuries before the

1 All references are to Suśruta-saṃhitā and they point at parallels in Celsus's De Medicina. Meulenbeld points at similarities in medical and surgical treatments of growths (hernia-antra-vrddhi, hydrocele- mütraja-vrddhi or scrotal tumour-medaja-vrddhi), rhinoplasty, fractures and dislocations, extraction of teeth and surgical treatments of a number of eye diseases like cataract, pterygium and entropion; split earlobes and their repair. There are similarities in the discussion on characteristics of incurable patients as well. Meulenbeld does not mention Sostratus though.

2 Author's note: 'The name of Chandragupta is written by the Greeks as Sandrokottos, Sandrakottas, Sandrakottos, Androkottos, and (best) Sandrokuptos'.

3 Megesthenes, the Greek ambassador sent to India by Seleucus in his account of India he had written interesting accounts of a ruler Sandracottus who had his court at Pālibothra at the junction of the rivers Ganges and Erranaboas. It had remained a mystery as to what these names referred to. Although Pātaliputra i.e. Patna was a fair guess. Yet the river Ganges and river Son were known to meet at this place in ancient times. William Jones accidentally came across the synonym of river Son as Hiranyabāhu and identified it with Erranaboas. He also came across the name of Candragupta as a ruler of Pătaliputra and that he received Greek ambassadors there. He could then put two and two together and surmise that Sandracottus must have been Candragupta.

${ }^{4}$ Suśruta was son of Visvāmitra who learnt the science of medicine from Divodāsa, whose family name was Dhanvantarī and was the king of Vārānasī or Banares. Both Visvāmitra and Divodāsa alias Dhanvantarī are legendary figures often mentioned in ancient Indian medicine. Dhanvantari was supposed to be the originator of the school of surgery and it has become a generic term for physician-surgeons in Ayurvedic medicine. As the story goes, after learning the techniques from Dhanvantarī, Suśruta wrote the earliest version of $S S$ and it is given an approximate date of a few centuries before the Christian era. After a number of revisions, the version we have now, is the one known to have been revised by Nāgārjuna who also added the last chapter himself. Thus modern-day SS has a layered structure of which earliest layers can be attributed to Suśruta. 
Christian era. Major revision was done by Nāgārjuna who also added the last chapter around first/second century CE. ${ }^{5}$

On the contrary, not much is known about Sostratus, the surgeon and his work except for scant references by these three famous Roman writers. Moreover, modern scholars who mention him have one or more of the aforesaid writers as their source, the fact amply demonstrated by Wellman (Wellman, 1891). Gossen's note on Sostratus-the wound surgeon is interesting in this regard (Pauly-Wisdowa). ${ }^{6}$

Sostratus was a common name among Greeks and Romans. There was a well-known Greek engineer who was called Sostratus of Cnidus and he flourished around 300 BCE (Grant, 1988, p. $314,339)$. He was an architect in Alexandria and built a great lighthouse which became one of the Seven Wonders of the ancient world. He apparently had nothing to do with medicine. Athenaeus (Burton, 1853-54, p. 1, 3, 85, 37, 101, $361,405)$, a Roman writer of late $2^{\text {nd }}$ century CE in his massive Deipnosophists (Philosophers at supper) has described Greek history in the context of the Roman Empire. He, indeed, records three persons by the name Sostratus. One was 'attached to King Antiochus I' ( 322-261 BCE, Son of Seleucus Nicator) and was 'a flute player'. The second was a 'parasite of Cavarus, the Gaul' and the third one was a 'writer of zoology' (Aelian, $1958,5.27,6.51) .{ }^{7}$ None of them is identified as a physician, or a surgeon. We note that Sostratus the zoologist has been copiously quoted, a gist of which is provided by Wellman.

All in all, it seems that Sostratus, the zoologist was well-known, but the physician-surgeon was a relatively unknown personality. He was known only in the contemporary medical circles. Considering the scant references, it seems they also knew very little about him and his life. Nothing is known, either about his parents, and family, his works, except for what is recorded by the three Roman medical writers/compilers, Celsus, Soranus (Temkin, 1956, p. 195, 197, 214) and Galen (Kuhn, 1965, p.184) which we discuss below.

About these writers there is one fact in common. While writing on any topic they extensively studied works of earlier authors and selectively added them to their own experience. Thus, these works are repository of medical wisdom till each of their respective times of writing. It is true in the case of Hippocratic corpus as well. It is now known to be work of several authors who lived around 400 BCE. Owsei Temkin writes about Soranus as:

\footnotetext{
5 It is generally accepted that Suśruta-samhitā underwent three major revisions, first it was revised by Nāgārjuna in the first/ second century CE. Jejjața wrote commentary on Suśruta-samphitā in the $9^{\text {th }}$ century CE. It was later revised by Candrața in the $10^{\text {th }}$ century CE taking into consideration Jejjața's commentary. Lastly there is a commentary by Dalhana in the $12^{\text {th }}$ century CE. According to Dalhạ̣a, the last chapter Uttaratantra was written by Nāgārjuna himself. For a detailed account on this work, its layers, contents, date, historical references, important commentaries etc see Meulenbeld, 1999.

6 According to Wellmann S., in a contribution to the source analysis of Aelian, Herm. XXVI, $32 \mathrm{ff}$, he lived in Alexandria after 30 BC. His medical writings, whose titles were mainly concerned with obstetrics, (p.224 R.), but he also did other operations such as bladder-cut (368) and treated the umbilical hernias which he attributed to various causes (Celsius VII, 14) and the abdominal fistulae.

7 A F Scholfield, the translator, writes a note on Sostratus in the index of authors cited by Aelian. It is as follows. "Sostratus, of Alexandria, fl. end of 1st century BCE, surgeon and zoologist, 5.27, 6.51; p. xviii, xxiv)" A F Scholfield does not support his claim of Sostratus being a Roman surgeon. All the references he provides are from Aelian and they are all to Sostratus, a zoologist. A F Scholfield perhaps relies on Celsus and Soranus when he records Sostratus as a surgeon. A F Scholfield, in the introduction part, (p. xviii and xxiv) further expresses doubts as to whether Aelian had actually referred to the authors he quotes or only to excerpts in other works. Other historians of antiquity also refer to one Sostratus who was in the army of Alexander the Great. He has said to have joined Herolaus in a plot to kill Alexander. He was obviously not Sostratus the surgeon or the zoologist (See Arrian, 1976-781, p.383).
} 
If Soranus' fame as an obstetrician has survived into our own days, this is mainly due to the obstetrical sections of his book. It must, of course, be realized that Soranus was much dependent on his predecessors, especially Herophilus and his school. Their works being lost, Soranus, apart from the short chapter in Celsus, thus emerges as our main authority after Hippocrates. His Gynecology represents a body of knowledge gathered by Soranus, but not altogether his original creation (Temkin, 1956, p. XI).

\subsection{Case of Celsus}

Aulus Cornelius Celsus (25 BCE-50 CE) was a Roman medical writer and compiler. He was a figure of the period of Roman emperors Augustus (63 BCE to $14 \mathrm{CE}$ ) and Tiberius (42 BCE to 37 $\mathrm{CE})$. It is possible that he was not a physician himself but his writings collate information including medicine till his time. In his complete work De Artibus, Celsus has written on topics ranging from agriculture, military art, philosophy, jurisprudence and medicine (Krumbhaar, 1941, p. 204). He has written extensively on surgery where he chiefly used Greek sources. His book number seven viz., De Medicina constitutes medicine and a large part of it is devoted to ophthalmology including ophthalmic surgery. It contains the earliest narration of the procedure of cataract surgery in western literature (McVaugh, 2001, pp. 45, 319-340). Celsus's importance lies in the fact that his is the earliest encyclopedic work on Greek and Alexandrian medicine to come down to us. As a matter of fact, little was known of him and his work till the thirteenth century when Pope Nicholas (1397-1455 CE) chanced to rediscover it.

Celsus (Page, 1935, pp. 295, 309, 377) mentions Sostratus thrice in his book on medicine De Medicina, firstly as an exponent of surgery, secondly as the one who has not mentioned omentum as a cause of umbilical hernia, and the third time as the one who believes that fistulas in the belly are incurable.

\subsubsection{Sostratus as an exponent of surgery}

Celsus writes:

This branch, although very ancient, was more practiced by Hippocrates, the father of all medical art, than by his forerunners. Later it was separated from the rest of medicine, and began to have its own professors; in Egypt it grew especially by the influence of Philoxenus, who wrote a careful and comprehensive work on it in several volumes. Gorgias also, and Sostratus and Heron, and the two Apollonii and Ammonies, the Alexandrians, and many other celebrated men, each found out something (Page, 1935, p. 309).

From the above account it appears that Celsus was well aware of the state and progress of surgery at the time of Hippocrates (460/59-355 BCE) and after. He knew about the evolution of the field of surgery in Egypt as well as many other places.

It is interesting to note that Suśruta in turn also mentions Greeks as yavana, stating that a particular kind of leeches come from them. Caraka, the ancient Indian expert of medicine, also mentions yavana (Greeks) as meat-eaters (Pandeya, 1970, pp.300-316).

तासां यवनपाण्डयसह्यपौतनादीनि क्षेत्राणि; तेषु महाशरीरा बलवत्यः शीघ्रपायिन्यो महाशना निर्विषाश्च विशेषेण भवन्ति। १९३।।

tāsām yavanapāṇdyasahyapautanādini kṣetrāni ; teṣu mahāśarīrā balavatyaḥ śīghrapāyinyo mahāśanānirviṣāśca viśeșeṇa bhavanti ||13\|

(SS, Sūtra, 13.13)

Among them some are from the countries such as Greece (yavana), the Deccan (pāndya), the tract of land traversed by the ghät mountains (sahya), and pautana (modern Mathura). (The leeches found in the aforesaid countries), they are especially nonvenomous, with strong, large bodies, greedy and are ready suckers (pāyina).

\subsubsection{Sostratus as the one that has not mentioned omentum as a cause of umbilical hernia}

It was in the thirteenth century $\mathrm{CE}$ that the surgical treatment of hernia became known in the west (McVaugh, 2001, p. 321). It was a forgotten tradition for over a millennium during the so- 
called Dark Ages. It was practiced during Celsus's time as seen below. Celsus writes:

There are also around the naval many lesions about which, owing to their rarity, there is little agreement among authorities. But it is probable that each has passed over what was unknown to himself; while no one has depicted what he had not seen. Common to all cases is an ugly prominence of umbilicus, and the causes are sought for. Meges gave three, rupture into it of the intestine, of the omentum, or of humour. Sostratus said nothing about the omentum, in addition to the other two he said that at times there was increase of flesh in that part, sometimes sound, sometimes cancerous. Gorgias himself also omitted mention of the omentum (Page, 1935, p. 377). ${ }^{8}$

Let us see what Suśruta has to say about hernias and umbilical protrusion. Suśruta (Kunjalal, 1998) ${ }^{9}$ has mentioned hernia (antra-vrddhi), hydrocele (mütraja-vrddhi) or scrotal tumour (medaja-vrddhi) in a chapter Nidānasthāna providing a detailed account. ${ }^{10}$

अन्त्रवृद्धया विना षड्या वृद्धयस्तासु वर्जयेत्।

अश्वादियानं व्यायामं मैथुनं वेगनिग्रहम्।।३।।

अत्यासनं चङ्रमणमुपवासं गुरूणि च।

तत्रदितो वातवृद्धौ त्रैवृतस्तिधामातुरम्। 18 ।।

स्विन्नं चैनं यथान्यायं पाययेत विरेचनम्।

कोशाम्रतिल्वकैरण्डफलतैलानि वा नरमू।|४।।

सक्षीरं वा पिबेन्मासं तैलमेरण्डसम्भवम् ।

ततः कालेउनिलघानां क्वाथैः कल्कैश्च बुद्धिमान् । ६ ।।

antravrddhyā vinā șadyā vrddhayastāsu varjayet | aśvādiyānam vyāyāmam maithunam veganigraham $\|3\|$

atyāsanam cañkramañamupavāsam guruṇi ca | tatrādito vātavrddhau traivrtasnigdhamāturam $\|4\|$ svinnam cainam yathānyāyam pāyayeta virecanam | kōśámratilvakairandaphalatailāni vā naram $\|5\|$ sakșīram vā pibenmāsam tailamerandasambhavam | tatah kāle 'nilaghnānām kvāthaị kalkaiśca buddhimān $\|6\|$

(SS Ci, 19.3-6)
'In the six types of $v r d d h i$ other than the one known as the antra-vrddhi (hernia), riding on horseback, etc. excessive physical labour, fasting, sitting in an unnatural position, constant walking, voluntary restraint of any natural urging (for stool or urine etc.) sexual intercourse, fasting and eating food of difficult digestion should be avoided. In the vătaja type of $v r d d h i$, the patient should be first soothed (snigdha) with the application of traivrta ghrta (vide, chap. V. $S S, C i$.) He should then be duly fomented and subjected to a proper course of purgatives. As an alternative, he should be made to drink the expressed oil of the kośämra, tilvaka or eranda (castor) oil (as a purgative) with milk for a month. A decoction of $v \bar{a} y u$ subduing drugs mixed with the powders of the same drugs should then be employed by an experienced physician. ( $S S, C i, 19.3-6)$

भारहरणबलवद्विग्रहवृक्षप्रपतनादिभिरायासविशेषैर्वायुरभिप्रवृद्धः प्रकुपितश्च स्थूलान्त्रस्येतरस्य चैकदेशं विगुणमादायाधो गत्वा वङ्क्षणसन्धिमुपेत्य ग्रन्थिरूपेण स्थित्वा अप्रतिक्रियमाणे च कालान्तरेण फलकोशं प्रविश्य मुष्कशोफमापादयति, आध्मातो बस्तिरिवाततः प्रदीर्घः स शोफो भवति, सशब्दमवपीडितश्चोर्ध्वमुपैति, विमुक्तश्च पुनराध्मायते, तामन्त्रवृद्धिमसाध्यामित्याचक्षते। ।६।।

bhāraharaṇabalavadvigrahavrksaprapatanādibhirāyāsaviśeșairvāyurabhipravrddhah prakupitaśca sthūlāntrasyetarasya caikadeśam vigunamādāyādho gatvā vanksṣanasandhimupetya granthirūpena sthitvā apratikriyamāne ca kālāntarena phalakoșam praviśya mușkaśophamāpādayati, ädhmāto bastirivātatah pradīrghah sa śopho bhavati, saśabdamavapìditaścordhvamupaiti vimuktaśca punarādhmāyate, tāmantravrddhimasādhyāmityācakșate||6\|

(SS, Ni, 12.6).

The local wind $(v \bar{a} y u)$ enraged and unusually aggravated by lifting a great load, wrestling with a stronger person (violent physical strain) or a fall from a tree and such like physical labour doubles up a part of the small intestine and presses it down into the inguinal regions lying there strangulated in the form of a knot (granthi) which is known as antra$v r d d h i$ (inguinal hernia). The part not properly

\footnotetext{
8 'Sostratus nihil de omento dixit: duobus iisdem adiecit carnem ibi interdum increscere, eamque modo integram esse, modo carcinomati similem.' A Cornelii Celsi, De Medicina, vol 7 part 14 (Loeb Classical Library edition).

9 One finds antra-vrddhi or 'growth of intestine' i.e. hernia in SS, Ni 12.6 and also its treatment in Ci, 19.17, 20. Treatments of andakoșa/phalakoṣa/vruṣana or scrotum (or scrotal tumour) and hydrocele are discussed in SS, Ci 19.15, 16 respectively.

${ }^{10}$ Again Suśruta discusses scrotum (andakoșa/phalakoșa/vrṣaṇa), median line of the perineum (sevanī) and phala (testes). Suśruta differentiates a $v r d d h i$ or growth into seven kinds. Different physical appearances of affected scrotum are named as sub-categories of $v$ rddhi $(S S \mathrm{Ni}, 12.2)$.
} 
attended to at the outset descends into the scrotum which becomes ultimately elongated and intensely swollen and looks like an inflated air bladder. It (hernia) ascends upwards under pressure, making a peculiar sound (gurgling); while let free it comes down and again gives rise to the swelling of the scrotum. This disease is called antra-vrddhi and is incurable.

It appears that Suśruta is talking here about inguinal hernia caused by the swelling of the intestine. He has recorded the causes and also discussed its behavior when pressed; e.g. "It (hernia) ascends upwards under pressure, making a peculiar sound (gurgling); while let free it comes down and again gives rise to the swelling of the scrotum". These characteristics, viz. the descending of the swollen or projected part to its normal place, and also making a sound, are noted down by Celsus as well (Page, 1935, p. 380). ${ }^{11}$

From Celsus's account it seems Celsus himself knew both the kinds of hernia, inguinal and umbilical. Celsus further points out that Sostratus does not talk about omentum as the cause of umbilical protrusion i.e. umbilical hernia. Omentum is one of two double folds of Peritoneum that hang down like aprons from the liver and stomach over the coils of small intestine. Indeed one does not find omentum, mentioned in Suśruta's work. Suśruta does mention the protrusion of umbilicus though.

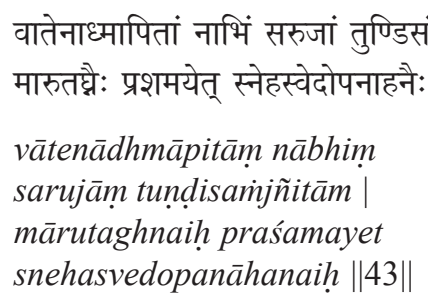

$(S S S \bar{a}, 10.43)$

If the umbilicus is swollen due to humor wind then it is called tundinābhi (prominence of navel). It is to be relieved using oiling, sweating and poultice.
Celsus calls it the "ugly prominence of umbilicus'. Although Suśruta does not clearly mention vrddhi i.e. hernia in this case, the translator has related it to umbilical hernia. Kavi rāj Ambika Datta Sastri writes a note, "There is a possibility of tuṇdinābhi developing into umbilical hernia".

Incidentally, Suśruta's treatment of tundinābhi sketched in the above verse is similar to the one he advises for the $v r d d h i$ caused by humor wind. Both of them use oiling, sweating and poultice.

All things considered, Suśruta does differentiate between two kinds of growth one which extends down the scrotal sac, and the other which does not. ${ }^{12}$ The first kind is considered as incurable and the second as curable. In Celsus's words, the second could be called 'sound' for being curable and the other as 'cancerous' for being incurable. In this way, Suśruta mentions inguinal hernia and its two types, one sound and the other cancerous. Suśruta does not mention omentum as a cause of protrusion of the navel but the humor wind. This is indeed in agreement with what is recorded by Celsus that Sostratus attributes the cause of umbilical protrusion to a humor and not to omentum.

In this way, all three peculiarities with respect to hernia mentioned and attributed to Sostratus by Celsus are indeed in agreement with Suśrutasaṃhitā.

\subsubsection{Sostratus as one who believes that the fistulas in the abdomen are incurable}

Celsus writes, "There is no bone in the abdomen; but all the same fistulas there are so dangerous; that Sostratus thought them incurable. Experience, however shows that this is not always the case" (Page, 1935, p.309).

\footnotetext{
${ }^{11}$ Celsus says, "When the intestine has prolapsed the swelling-increases not only under heat of all kinds but also when the breath is held. At intervals it rumbles, and if the patient lies down on his back the swelling subsides, as the intestine has slipped back."

${ }^{12}$ Further "A case of antra-vrddhi (hernia when strangulated) extending down the scrotal sac (koṣa) should be given up as irremediable; but in the case of its not being so extended, it should be treated as a case of vätaja-vrddhi."
} 
Suśruta mentions bhagandara i.e. fistula in his nidānasthāna in the fourth chapter. Bhagandaras are in fact the fistulas of the parts, which lead to the vulva, since bhaga is vulva or the pubic region. He states that "The disease is so named from the fact that it bursts the rectum, the perineum, the bladder and the place adjoining to them". [Celsus called it 'belly'.] Suśruta has classified the fistulas in five categories. He states that "bhagandaras are in general hard to cure and some are incurable". ${ }^{13}$ The incurable bhagandaras are those formed due to the concurrence of three ${ }^{14}$ and also those, which are ksataja i.e. formed by injury. For others Suśruta suggests cures using a probe, keeping fasts, taking purgatives, cauterization, bloodletting and dressing etc.

घोराः साधयितुं दुःखाः सर्व एव भगन्दराः।

तेष्वसाध्यस्रिदोषोत्थः क्षतजश्च भगन्दरः।।१३।।

ghorāh sādhayitum duhkhāh

sarva eva bhagandaräh

teșvasādhyas tridoṣotthah

kșatajaśca bhagandarah $\|13\|$

(SS, Ni. 4.13)
Almost all the type of this disease yield to medicine after a prolonged course of treatment, they are difficult to cure, except the sannipāta and traumatic ones which are incurable.

पश्च भगन्दरा व्याख्याताः, तेष्वसाध्यः शम्बूकावर्तः शल्यनिमित्तश्च; शेषाः कृच्छ्रसाध्याः।।३।।

pañca bhagandarā vyākhyātāh, teșvasādhyah śambūkāvartah śalyanimittaśca; śeșạh krcchrasādhyāh $\|3\|$

(SS, Ci 8.3).

Five bhagandaras i.e. fistulas the two, known as śambūkâvarta (tridoșaja i.e. caused by the concurrence of (imbalance of) three doșas and śalyaja (traumatic) are incurable, and the rest are extremely difficult to cure.

Celsus also considers some fistulas to be particularly difficult to cure and suggests a special treatment for them. Both Suśruta and Celsus have warned that a rash movement after the surgery (SS, Ci 8.8, 9; Page, 1935, p.453-454) $)^{15}$ could lead to the failure of the treatment. It is interesting to note that Celsus also mentions a traumatic injury as the cause of the graver fistula. He also warns about the risks involved where the patient could die (Page, 1935, p.311). ${ }^{16}$ He refutes Sostratus's statement regarding their incurability though.

\footnotetext{
${ }^{13}$ Five kinds of Fistulas are discussed in SS Ni, 4.1,2. He says, 'The deranged vāyu, pitta, kapha and sannipāta (the simultaneous derangement of the three bodily dosas) and extraneous causes (such as a blow etc.) give rise to the types of bhagandara known as sataponaka, uștragrīva, parisrāvī, śambūkāvarta and unmārgi. The disease is so named from the fact that it bursts the rectum, the perineum, the bladder and the place adjoining to them (thus setting up a mutual communication between them). The pustules which appear in these regions are called as pidakas in their unsuppurated stage, while they are called bhagandara when they are in a stage of suppuration." A pustule, appearing about the region of the anus and characterized by a slight pain and swelling and immediately subsiding, should be regarded as a simple pustule, others are called bhagandara.

${ }^{14}$ According to tridoșa theory body is sustained by the three elements or 'dhātu', which are kapha, the phlegm, vāta, the wind and pitta, the bile. These are essential for the growth and maintenance of the body, a balance of the three keeps body in good, healthy state. An imbalance of the three on the other hand causes illnesses. Thus when a dhätu is rendering an adverse effect due to its being in deficit or excess, it is called as a 'doșa'. Any illness is characterized by either one or more of the dosas. Sometimes all the three doșas together cause a diseases in which case it is called as due to sannipatta or concurrence of the doșas.

${ }^{15}$ In the surgical treatment of fistulas both Celsus and Suśruta discuss various incisions characteristic of the part of the body and malady involved. Both of them advice a cross-shaped incision for treating the fistula and ulceration near the perineal region.

${ }^{16}$ Right after the mention of Sostratus, Celsus writes, "Indeed — and this may seem very remarkable — a fistula which forms over the liver, spleen, or stomach, is safer than one right over the intestine, not because a fistula there is more harmful, but because it opens the way to another danger. Some writers who have had experience of this have shown little perception of the true facts. For often the abdomen is actually penetrated by a weapon, and prolapsed intestines are replaced, and sutures bring the margins of the wound together and how this is done I will presently point out. Therefore also a fine fistula breaks through the abdominal wall, it is possible to cut it out, and to join its margins by suture. But if such fistula widens out inside, its excision necessarily leaves a wide gap which cannot be sutured without applying great force, especially in the deeper part where the abdomen is enclosed by a kind of membrane which the Greeks call peritoneum. Therefore, when the patient begins to get up and move about, the sutures break, and the intestines prolapse; which causes his death. But the cases are not altogether desperate, and so for the finer fistulae, treatment is to be adopted."
} 


\subsection{Case of Soranus}

Sorano or Soranus of Ephesus was a physician first in Alexandria and then in Rome where he was a contemporary of Trajan and Hadrian, about CE 100. He was called the Prince of the Methodists and founder of obstetrics and gynecology (Krumbhaar, 1941, p. 202). Very little is known of his writings since most of his works are lost. From whatever is extant in Greek, in Byzantine medical encyclopedias and in Latin translations made by Caelius Aurelianus ( $4^{\text {th }} / 5^{\text {th }}$ century CE), it appears Soranus wrote on a wide range of topics like internal medicine, surgery, ophthalmology, materia medica, hygiene etc. Out of some twenty works that are credited to him, 'gynecology' is considered as the most important one. It is an incomplete work reconstituted from a gynecological miscellany contained in a single fifteen-century manuscript (Flemming, 2000, p. 229). Soranus in his work entitled On Midwifery and the Diseases of Women mentions Sostratus twice (Temkin, 1956, p. 195, 197).

\subsubsection{Case of afterbirth or placenta retention}

In the case of natural delivery, after the umbilical cord is cut off, the child starts breathing on its own and begins its independent life. The placenta, which is the disc shaped structure in the uterus that provides nourishment to the fetus, and chorion, the extra-embryonic membrane, which joins the placenta to the uterus, both are expelled a little later and are therefore called the afterbirth (The word for placenta in Sanskrit aparā is analogous). Under some abnormal circumstances, if the placenta and chorion does not come out naturally after the birth of the child, it has to be made to come out using certain methods. Otherwise it causes inflammation and it leads to complications that could put mother's life in danger. Ancient medical writers including Suśruta,
Soranus as well as the Chinese doctors, were aware of the fact that retained placenta was a grave situation and it needed to be tackled immediately, therefore they employed various methods to deal with this problem. They tried methods like fumigation of certain objects having repulsive odor, or used a sternutator i.e. an agent that induces sneezing, close the nostrils that would give a jolt to the mother and with that force, placenta would come out. At times, diuretics were employed too. Shaking the mother physically was yet another way. Surgical intervention to remove the retained placenta was adopted as a last resort. Indian and Greek/Roman writers handled this problem in many ways. These methods are narrated in the writings of Suśruta as well as Soranus.

Soranus mentions Sostratus as he writes the methods to bring down the placenta.

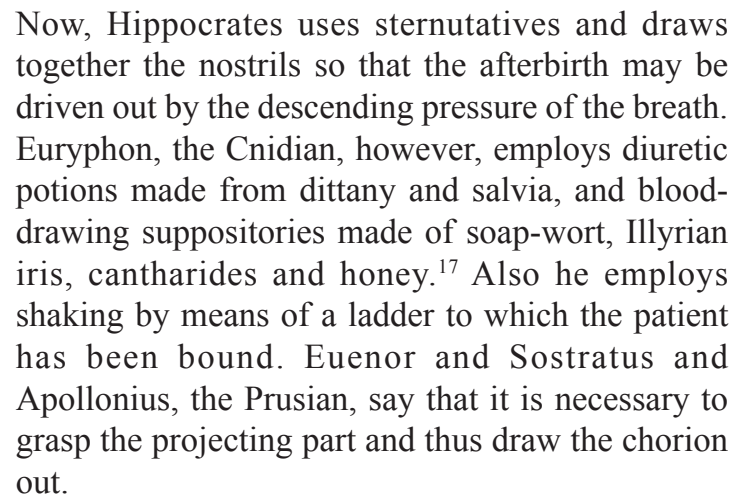

Suśruta discusses a number of methods for the extraction of retained placenta which were on similar lines as those of Soranus. They were called aparāpātana where apar $\bar{a}$ is placenta (secundines) ${ }^{18}$ and pātana is 'making something to drop down'. He suggests surgical/manual removal of retained placenta as a last resort.
शुक्रं दुष्टं शोणितं चाङ्गनानां
पुष्पोद्रेक तस्य नाशं च कष्टम्।
मूत्राघातान्मूत्रदोषान् प्रवृद्धान्
योनिव्याधिं संस्थितिं चापरायाः । १९२५ ।।

\footnotetext{
${ }^{17}$ Suśruta also advises the use of a suppository for the expulsion of retained placenta. Furthermore uses of vaginal suppository listed by Suśruta include the expulsion of retained placenta as well.

${ }^{18}$ Aparā means the other, later, latter, second or that which comes after. It is thus synonymous with 'secundines' and 'afterbirth'
} 
śukrạ̣ duṣtam śoṇitạ̣ cāniganānāṃ

puṣpodrekam tasya nāśam ca kaṣtam |

mūtrāghātānmūtradoṣān pravrddhān

yonivyādhị̣ saimsthitim cāparāyāḥ ||125||

शूक्रोत्सेकं शर्करामश्मरीं च

शूलं बस्तौ वड्ष्कणे मेहने च।

घोरानन्यान् बस्तिजांश्चापि रोगान्

हित्वा मेहानुत्तरो हन्ति बस्तिः।।9२६।।

śūkrotsekam śarkarāmaśmarīm ca

süulam bastau vankșaṇe mehane ca|

ghorānanyān bastijāimścāpi rogān

hitvā mehānuttaro hanti bastih $\|126\|$

Diseases such as derangements of the semen, or of ovum, or difficult menstruation, excess or suppression of the monthly flow, diseases of the uterus and of the vaginal canal, non-falling of placenta, strangury and other diseases of the urine, gravel, stones (aśmarì), spermatorrhea (śukrotseka), cramps in the bladder other than meha, will all yield to the application of uttarabastī.

$(S S, C i, 37.125,126)$

अथापराइपतन्त्यानाह-आध्मानौ कुरुते, तस्मात् कण्ठमस्याः केशवेष्टितयाडड़्या प्रमृजेत्, कटुकालाबुकृतवेधनसर्षपसर्पनिर्मोकैर्वा कटुतैलविमिश्रैर्योनिमुखं धूपयेत्, लाड्गलीमूलकल्केन वाडस्याः पाणिपादतलमालिम्पेत्, मूहिन वाडस्या महावृक्षक्षीरमनुसेचयेत्, कुष्ठलाड़्लीमूलकल्कं वा मद्यमूत्रयोरन्यतरेण पाययेत्, शालमूलकल्क वा पिप्पल्यादिं वा मद्येन, सिद्धार्थककुष्ठलाड़्लीमहावृक्षक्षीरमिश्रेण सुरामण्डेन वाड्स्थापयेत्, एतैरैव सिद्धेन सिद्धार्थकतैलेनोत्तरबस्तिं दद्यात्, स्निग्धेन वा कृत्तनखेन हस्तेनापहरेत् । २११।

athāparā'patantyān-āhādhmānau kurute, tasmāt kanthamasyāh keśavestititayā'ngulyā pramrjet, kațkālābukrtavedhanasarșapasarpanirmokairvā katutailavimiśrairyonimukham dhūpayet lānalìmūlakalkena vā'syāh pānipādatalamālimpet mūrdhnim vā'syā mahāvṛssakșīramanusecayet, kușthalāinalīmūlakalkaì vā madyamūtrayoranyatareṇa pāyayet, śālamūlakalkam vā pippalyādim vā madyena, siddhārthakakușthalāingalīmahāvrkșakșīramiśrena surāmaṇdena $v \bar{a}$ 'sthāpayet, etairaiva siddhena siddhärthakatailenottarabastim dadyāt snigdhena vā krttanakhena hastenāpaharet $\|21\|$

$(S S, S a, 10.21)$

The retention of placenta causes distention and inflammation. Therefore her (mother's) neck should be tickled with a finger to which hair is wrapped round. Fumigate the vaginal opening with mustard seed, cast-off skin of a snake mixed with that of oil of plant katukālābu or katutaila i.e. bitter oil (that of white mustard). Smear her palms and soles of the feet with paste of the root of plant lāngalī; or sprinkle on her head the milk of plant mahāvrkșa, make her drink the powdered root of plants kușta and lāingali in alcoholic liquor or urine. Or else, powdered root of plant sāla or pippalī in alcoholic liquor; mustard, kușta, lāingalī, milk of mahāvṛsṣa mixed with surämanda should be placed on (the vaginal opening). Or else, do it with oiled hand with paired nails.

Suśruta's verses that describe the removal of placenta by pulling are as follows:

अथापतन्तीमपरां पातयेत् पूर्ववद्रिषक्।

हस्तेनापहरेद्वाडपि पार्श्वभ्यां परिपीड्य वा ।११७।।

athāpatantīmaparām

pātayet pūrvavadvibhișak

hastenāpaharedvā'pi

pārśvabhyām paripịdya vā $\|17\|$

If the placenta does not come out then the physician should bring it about using methods told earlier i.e. in the earlier chapter (śārirasthāna) or by pulling with hand or by exercising pressure on the sides.

Also at the time of the delivery Suśruta instructs the physician to catch hold of the umbilical cord and pull it out.

ततो नाभिनाडीमष्टाड़लमायम्य सूत्रेण बध्द्धा छेदयेत्, तत्सूत्रैकदेशं च कुमारस्य ग्रीवायां सम्यग् बघ्ननीयात्। $192 । ।$

tato nābhināḍ̂maștāingulamāyamya sūtreṇa baddhvā chedayet, tatsūtraikadeśạ̣ ca kumārasya grīvāyām samyag badhnīyāt ||12||

(SS Śa 10.12)

Now the umbilical cord should be pulled out eight fingers length, then tied with a thread (to avoid blood loss) and cut. One end of the thread should be properly tied to the infant's neck (so that natural movements of the infant would draw the placenta out).

Hand insertion is to be used as a last resort in Suśruta's opinion. Whereas Soranus does not, in fact, approve of many of the above methods and discusses the risks involved in all of them. $\mathrm{He}$ further suggests the best method as inserting the hand and gently removing it afterbirth. 


\subsubsection{Removal of the dead fetus}

Soranus' second reference to Sostratus is with respect to removal of the dead fetus and also surgical removal of urinary calculii. He writes:

If the fetus is in transverse position or is folded up, and cannot be straightened, one should cut into the parts which are presenting - in some cases the abdomen, in others the armpits, the intercostal spaces, or in the region of the kidneys in the direction of the flanks. If the fetus is dead and of excessive size, it is dangerous to morcellate it entirely within the uterus. It is better to cut each of the parts as it presents. In these cases amputations at the points are indicated. Often, however, because of the traction exerted upon the feet by inexperienced persons, the head is torn off and is hard to grasp because of its rounded shape and because it slips away into the uterine cavity. In such cases, just as in stones of the bladder, Sostratus introduces the finger of the left hand into the anus while pressing with the right hand upon the abdomen, and tries to bring down the head (Page, 1935, p. 431). He does not see that in rectum, finger cannot reach the head. For whereas the bladder is readily accessible, the uterus extends far beyond, as we have shown above.

It is interesting to note that the procedure narrated by Celsus is also on similar lines, he refers to lithotomy. He writes, "The surgeon in lithotomy introduces first the index finger, then the middle finger of the left hand into the anus". A method for the removal of placenta after the fetus is delivered is described by Celsus which is similar to Suśruta's with respect to drawing the navel cord using left hand and removing the placenta (Page, 1935, p.461). ${ }^{19}$

In the above passage Soranus, in fact, refers to two of Sostratus' surgeries, one is the removal of dead fetus and the other is lithotomy. Soranus claims that Sostratus employs similar techniques in both the cases. Soranus does not consider the technique (which constitutes insertion of two fingers of the left hand by the surgeon into the rectum of the patient and bringing down the particular object to be removed) would be effective in the case of the removal of dead fetus. Apparently, he approves of Sostratus' method with respect to lithotomy. Let us see what Suśruta says in these cases.

ततः स्वभ्यक्तनाभिप्रदेशस्य वामपार्व्वं विमृद्य मुष्टिना अवपीडयेत् अधोनाभेर्यावदश्मर्यधः प्रपन्नति, ततः स्रेहाभ्यक्ते कृप्तनखे वामहस्तप्रदेशिनीमध्यमे अडुल्यौ पायौ प्रणिधायानुसेवनीमासाद्य प्रयत्नबलाभ्यां पायुमेढ्रान्तरमानीय, निर्व्यलीकमनायतमविषमं च बस्तिं सत्रिवेश्य, भृशमुत्पीडयेदडुलिभ्यां यथा ग्रन्थिरिवोन्नतं शल्यं भवति। ३३०।।

tatạ svabhyaktanābhipradēśasya vāmapārśvam vimrdya muștina avapīdayet adhonābhery $\bar{a}-$ vadaśmaryadhah prapannati, tatah snehābhyakte krlptanakhe vāmahastapradeśinimadhyame à̃gulyau pāyau pranidhāyānusevan̄imāsādya prayatnabalābhyām pāyumeḍhrāntaramānìya, nirvyalīkamanāyatamavișamam ca bastim sanniveśya bhrśamutpị̄ayedañgulibhyām yathā gramthirivonnatam śalyam bhavati $\|30\|$

(SS, $\mathrm{Ci}, 30)$

Then oil and massage the umbilicus region and rub the left-back side of it, press with the hand with folded fingers under the umbilicus till the calculii comes down. Then with oiled left hand with paired nails, insert the index and middle finger into the anus and move up till it reaches the median line of the perineum. With efforts and force bring it in between the anus and penis, so that the calculii makes a projection there- depending upon the size of the calculii make a slit and — take it all out with forceps.

Indeed, Suśruta's lithotomy procedure is similar to the Celsus' and from above passage it appears Soranus is acquainted with it. It is as follows. It is interesting to note that Wellman explains that procedure of bringing the dead fetus at the mouth of mother's vagina and that of removing the stone both mentioned by Celsus and Soranus are quoted from the same source. Wellman also states that this procedure was an

${ }^{19}$ Celsus wrties, "Now as soon as the foetus has been extracted it should be handed to the assistant to hold on his upturned hands, and the surgeon with his left hand must draw gently upon the navel cord, so as not to rupture it, whist he passes his right hand along it up to what they call the secondines including the whole of the blood vessels and membrane he brings them down from the womb in the same manner, and extracts the whole together with any retained blood clot." 
innovation not often used in Greek medicine (Wellman, 189, p.341).

When Soranus writes, "In such cases, just as in stones of the bladder, Sostratus introduces the finger of the left hand into the anus while pressing with the right hand upon the abdomen, and tries to bring down the head." He is confusing between two separate procedures, rectal insertion for removing stones and vaginal insertion for removing the dead fetus. Soranus further writes, "He does not see that in rectum, finger cannot reach the head." In fact, Suśruta goes on in the same chapter to state that woman's uterus lies closer to the back of the rectum. He therefore warns the surgeon to be careful while performing urinary calculii operation upon women.

स्रीणां तु बस्तिपार्श्वगतो गर्भाशयः सत्रिकृष्टः, तस्मात्तासामुत्सझ्छच्छस्र्रं पातयेत्, अतोऽन्यथा खल्वासां मूत्रस्रावी व्रणो भवेत्। ।३३।।

strīnām tu bastipārśvagato garbhāśayah sannikrștah, tasmāttāsāmutsangavacchastrạ̣ pātayet, ato'nyathā khalvāsām mūtrasrāvī vraṇo bhavet $\|33\|$

(SS Ci, 7.33)

A women's uterus lies close to the back of the rectum. Therefore in their case, the surgical instrument should be inserted deep-seated or else it will cause a wound which will exude urine.

It thus appears that Suśruta has advised the use of rectal insertion of fingers in the case of lithotomy and insertion of left hand in vagina in the case of removal of dead fetus. The confusion must have arisen when the transfer of knowledge between Suśruta-Sostratus-Soranus took place since no surgeon in his right mind will suggest removing dead fetus through rectal insertion. Incidentally, Suśruta advises, if and when needed, straightening out the fetus that is presenting the transverse position and to practice morcellation, the description of which is close to Soranus' description of the same.

ततः स्त्रियमाश्वास्य मण्डलाग्रेणाड़लीशस्रेण वा शिरो विदार्य, शिरःकपालान्याहत्य, शङ्क्ना गृहीत्वोरसि कक्षायां वाऽपहरेत्;
अभिन्नशिरसमक्षिक टे गण्डे वा, अंससंसक्तस्यांसदे शे बाहू छित्वा, दृतिमिवाततं वातपूर्णोदरं वा विदार्य निरस्यान्त्राणि शिथिलीभूतमाहरेत्, जघनसक्तस्य वा जघनकपालानीति।।१२।।

tatah striyamāśvāsya maṇdalāgrenāninulīśastrena vā śiro vidārya, śirahkapāāānyāhrtya, śà்kunā grhītvorasi kakșāyām vāpaharet; abhinnaśirasamaksikūte gande vā, amsasamsaktasyāmsadeśe bāhu chitvā, drtimivātatam vātapūrnodaram vā vidārya nirasyāntrāṇi śithilībhūtamāharet jaghanasaktasya $v \bar{a}$ jaghanakapālānīti $\| 12||$

(SS Ci, 15. 12)
किम्बहुना-
यद्यदङं हि गर्भस्य तस्य सज्जति तद्रिषक ।
सम्यग्विनिहरेच्छित्त्वा रक्षेत्रारीं च यत्नतः।।१३।।

\section{kimbahunā- \\ yadyadangam hi garbhasya \\ tasya sañjati tad bhișak| \\ samyagvinirharecchitvā \\ rakșennārīm ca yatnatah $\|13\|$}

(SS Ci, 15. 13)

After comforting the mother, using a circular instrument cut open the head (of the dead foetus), catching hold of head and forehead bone cavity, holding with the crochet shaped instrument pull out. The foetus should be drawn out by pulling at its chest or at the shoulder with a śanku (forceps). Where (in case) the head would not be punctured and smashed, the foetus should be dawn out by pulling it at the cheeks or the eye sockets. The hands of the foetus should be severed from the body at the shoulders, when they (the shoulders) would be (are) found to have been obstructed (in the passage) and then the foetus should be drawn out. The abdomen of a child dead in the womb, should be pierced and the intestines drawn out, in the event of the former being swollen into a flatulent ( $v \bar{a} t a)$ distention like a leather bag (for holding water), as the procedure would remove the stiffness of its limbs, and then it should be drawn out. The bones of the thighs (jaghanakapāla) should be first cut out and removed, where the foetus would be found to have adhered fast to the passage with its thighs (jaghana). What more [to say)-whatever part of the fetus is stuck it should be cut and the physician should bring it out properly and save the mother's life with efforts.

(SS Ci, 15. 12, 13)

Suśruta uses a rectal suppository for the extraction of retained placenta too just like Soranus does. Thus, Soranus's narration is 
comparable to Suśruta's procedure in the case of extraction of retained placenta and lithotomy.

\subsection{Case of Galen and Pseudo - Galen}

Galen (CE129-216) was one of the most prolific and influential medical writers of the Roman period (Nutton, 1997, p.133). ${ }^{20}$ All of his works have not survived but those found in Greek and also in Latin and Arabic translations are testimony to his extraordinary scholarship. His works preserve the theories and practice of ancient medicine during and before his time. He extensively refers to Hippocrates, as the others did, and to almost every prominent medical personality of the time. Galen's gigantic work includes nine books on anatomy, seventeen on physiology, six on pathology, sixteen essays on pulse, and fourteen books on therapeutics. He also wrote thirty books on pharmacy.

Galen, in his work De Antidotes which forms a part of his book Ad Pisonem (Nutton, 1997, pp. 133-152 $)^{21}$, while writing about a certain antidote composed by Apollodorus states that it was recommended by Sostratus. ${ }^{22}$

Suśruta indeed devoted a large part of chapter named kalpasthana (i.e. toxicology and it covers eight sections) to antidotes. In fact, toxicology was one section, among eight in all, of Ayurveda right from its conception. ${ }^{23}$ The recipes chiefly made use of plants. It is possible that few recipes found way to ancient Greece either in their original or in some corrupt form. This phenomenon is also seen in Hippocratic corpus (Klaus, 1989, p. 88). ${ }^{24}$

Furthermore, in De fasciis by ps. Galenous (pseudo Galen), the author discusses bandages, including a pectoral wrap. Here three paragraphs mention Sostratus with respect to particular kinds of bandages (Kuhn, 1965, pp. 823-4).

CII: The 'theatrical' bandage is [the one] where, when it has been completed, it becomes like the right angles of 'little altars', when first the 'basket-shaped' 'wry-neck' has been bound on, ror like] the similarshaped 'crane', finishing off the 'breast-band' of Sostratos, the straight one with the 'suspensories'.

CIII: And [another] 'theatrical' [bandage] fits [or is appropriate for] the same cases. Here they first bind on again the straight 'breast-band' of Sostratos, the one some people call 'four-fold' [or: the quadriga].

CIV: Placing two straps along the back, we weave [or interweave] the simple rhombus in the manner of in the case of the straight 'breast-band'.

The first paragraph (CII) is not clear. Perhaps here the author describes the shapes and ways of fastening the bandage. The next two paragraphs (CIII and CIV) describe pectoral wraps that are placed on the back, straight and fast. There is a reference to a four-fold bandage or 'quadriga' as well.

Suśruta dwelt extensively on the topic of bandage. According to him various parts of the body need a different kind of bandage since their

${ }^{20}$ Nutton V, on the basis of Arabic sources, fixes year of Galen's death as $216 \mathrm{CE}$ as against an earlier date hitherto accepted.

${ }^{21}$ Nutton Vivian, after considering biographical, stylistic and doctrinal information concludes that Galenic corpus written for Pamphilianus is unlikely to be genuine. He considers Ad Pisonem as genuine and its date of composition is between CE 204 to 207.

22 The recipe is as follows, "Of the compound [drugs] the one put together by Apollodorus and recommended by Sostratos and all those who took it over from him, the one that is composed of the blood of the turtle is as follows: of the seed of wild cummin, one oxybaphon; of the dried blood of a sea turtle, 4 drachmas, 2 staters; of fawn's rennet, or failing that hare's rennet, 3 drachmas; of the blood of a kid, 4 drachmas. Mix them all together, combining them with the best wine, and put to one side. For its use: take [a quantity] the size of an olive, pound it with the best wine, and give half a kyathos to drink. If [the patient] vomits up the drug, give again the quantity of half an olive, as said before, and again if [he/she] throws it up again, give the quantity of a third of an Egyptian kyathos, as said before." Kuhn, C G Claudii Galeni Opera Omnia, in 20 volumes, vol 14, p. 184.

${ }^{23}$ Eight sections of Ayurveda are kāa $\bar{a} c i k i t s \bar{a}$ (therapeutics), śālākya (the science of diseases of the eye, nose, ears, mouth and throat), śalyāpahartrka (general surgery), vișāgaravairodhikapraśamana (toxicology), bhūtavidyā (psychiatry), rasāyana (rejuvenation), kaumārabhṛtya (paediatrics) and vajīkaraṇa (science of increasing vitality).

${ }^{24}$ In Hippocratic corpus in the section (On the diseases of women) pepper is mentioned thrice as 'the Indian medicine' 
shapes and modes of movement are different. Suśruta has, in all, discussed 14 kinds of bandages including pectoral wraps.

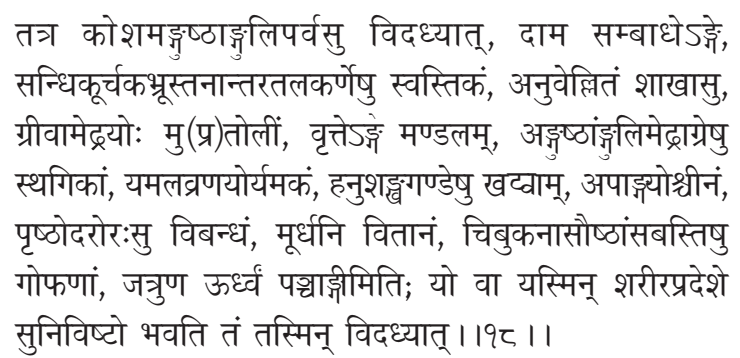

tatra kośamañgușthānguliparvasu vidadhyāt, dāma sambāadhe'nige, sandhikūrcakabhrūstanāntaratalakarṇeșu svastikaṃ, anuvellitam śākhāsu, grīvāmeḍhrayoh mu(pra)tolīm, vrtte'nge mandalam, angușthāngulimeḍhrāgreșu sthagikām, yamalavranayoryamakam, hanuśañkhagaṇeșu khațām, apāingayoścīnam, prșthodarorahsu vibandham, mūrdhani vitānam, cibukanāsauṣthāmssabastișu gophanām, jatruna ürdhvam pajcāngìmiti; yo vā yasmin śarīrapradeśe sunivișto bhavati tạ tasmin vidadhyāt $\|18\|$

There, the [different varieties are]: (i) kośa (eggshaped) is apples to the joints of the thumb and fingers; (ii) dāma (tail of a quadruped) is tied round a part for the relief of pain; (iii) svastika (portico shaped) is applies to the joints, to the spaces between the tendons of the great and second toe, to the eyebrows and the breasts, to the soles, palms and the ears (iv) anuvellita (encircling) is applied to the limbs; (v) pratoli (broad) is a broad bandage for the neck and penis; (vi) mandala (circular) is applied to round parts; (vii) sthagikā (giving firmness), a bandage filled with pastes, is applied to the end of the thumb, fingers and penis; (viii) yamaka (double) is applied to ulcers (ix) khatva (four tailed bandage) is for the cheeks, temples and lower jaw; (x) china (banner) is a bandage for the inner angles of the eyes; (xi) vibandha (a firm bandage) is for the back, abdomen and chest; (xii) vitāna (canopy) is a large bandage for the head, (xiii) gophana (a sling for throwing stones) is a concave bandage for the chin, nose, lips, shoulders and pelvis; (xiv) pañcāngī (or bandage with five tails) is for the parts above the clavicles. A bandage of any particular shape should be tied round th part of the body to which it would be found to be most suited.

(SS, Sutra, 18.18)

In fact, Suśruta suggests two of them to be used for bandaging abdomen, breasts and chest viz. the kinds svastika and vibandha. Svastika and khatva kind of bandage has four ends and the other vibandha bandage is the fast or tight one. This reminds one of ps-Galen's 'fast' and the 'quadriga' kinds of bandage used as a pectoral wrap.

In his commentary of Celsus' La Chirurgia, Mazzini who is the Italian translator and commentator of Celsus's work (Cornello, 1999, p. 564); writes a note on Sostratus, which goes as: Sostratus: Celsus mentions him three times, the first
( 7 praef.3) as an exponent of surgery, by now an
autonomous branch of medicine, in the context of
others, all Alexandrians, successors to Philoxenus,
such as Gorgia, Erone, the two Appoloni and
Hammonius, all famous, each because of having
discovered something in the scope of surgery; the
second time (7,4,3) for the opinion refuted by
experience, according to which the fistulas of the
stomach were supposed to be incurable; the third
time (7,4,1) for the conviction according to which
the umbilical hernia would not be a protrusion of
the 'omento', but an anomalous development of the
muscular texture, either healthy or 'carcinogenic; is
also cited by Sorano ${ }^{25}$, Galenous, the ps, Galenous
De fasciis, respectively regarding a particular
technique of gynecological intervention, an antidote
and a pectoral wrap; is to be placed in the second
half of the first century BCE". ${ }^{26}$

${ }^{25}$ Sorano or Soranus of Ephesus, the Prince of the Methodists and founder of obstetrics and gynecology, was a physician first in Alexandria and then in Rome, where he lived at the times of Trajan and Hadrian, about CE 100. Castiglioni, 1941 , p. 202.

26 "Sostratus: Celso lo menziona tre volte, la prima (7 praef.3) come un espnente chirungia, ormai branca autonoma della medicina, nel contesto di altri tutti alessandrini, successivi a Filosseno, come Gorgia, Erone, I due Appolloni e Hammonius, tutti celebri, ognuno per aver scoperto qualche cosa nell'ambito della chirurgia: la seconda (7,4,3), per l'opinione, smentita dall'esperienza, per cui le fistole del ventre sarebbero incurabili; la terza 7,14,1 per la convinzione secondo cui l'ernia ombelicale non sarebbe una protruzione dell'omento, ma uno sviluppo anomalo da tessuto muscolare, o sano o carcinomatoso. Viene citato ancora da Sorano, Galeno, dallo ps. Galenico De Fasciis rispettivamente a proposito di una tecnica particolare di intervento ginecologico, un antidoto ed una fascia pettorale. E da collocare nella seconda meta del I s.a.C."

Carcinomatosis is the state of widespread distribution of cancer throughout the body occurring at a late stage in many cancers. 


\section{Putting in Perspective}

So far we have seen that Suśruta and Sostratus belonged to more or less the same period and their surgical acumen was extraordinary. They both contributed in the development of the field of surgery. Certain procedures were known to be their sole expertise e.g. removal of retained placenta, morcellation of dead fetus for its easier removal without causing any harm to the mother and lithotomy or surgical removal of stones in the bladder. Furthermore, these procedures are prominently attributed to Suśruta and Sostratus in their respective cultures.

Celsus often refers to an Alexandrian physician Erasistratus (Greive, 1814, pp. 15, 33, 233). Erasistratus was a medical theorist and was one of the most celebrated physician-surgeon of Greek antiquity (Dickson, 1998, p.37). He was born in Cos (Ca.304 BCE?). ${ }^{27} \mathrm{He}$ lived at the court of Seleucus Nicator (358 -281 BCE) around 290 BCE (Grainger, 1990, p.153) and later in Alexandria. Seleucus himself was a Macedonian and contemporary of Alexander the Great; he was a high officer in Alexander's army and accompanied him in the campaigns of Bactria and India. Seleucus later founded the cities Seleucia on Tigris and Antioch near Syrian seacoast, thus founding the Seleucid Empire. He had contacts with India even after his campaign of India failed, just like Alexander's did before him. He was defeated by Chandragupta Maurya (Sandracottus as he is referred to in Greek) the king of Magadha, with its capital Pătaliputra or modern day Patna. Patna is a city on the banks of Ganges and about $275 \mathrm{kms}$ east of Banares or Varanasi that was traditionally known as Suśruta's place of work. They then agreed upon a mutually beneficial treaty, set up a relation by marriage and established contacts thereafter. Later, Megasthenes was sent by Seleucus to India and he acted as an ambassador in the court of Chandragupta. Megasthenes lived in Chandragupta's court between (302-298 BCE).The Seleucid Empire continued under Seleucus' descendants for nearly another 220 years. Separated from the Seleucid Empire, GrecoBactrian Empire continued till first century BCE. Thus the Greco-Bactrian-Indian contacts prolonged and acted as a stage for exchanges in various fields of knowledge. Artifacts found in Afghanistan point at Bactrian-Indian connection. Also indications to ancient Indian and Greek astronomical exchanges are found during the excavations of the theatre at Miletus, an ancient Greek city (Pingree, 1976, p. 143). Pingree writes:

\begin{abstract}
There existed extensive knowledge of India in the Hellenistic and Roman Imperial periods. Little was known of Indian astronomy, however. Undoubtedly, the most astonishing piece of evidence is an inscription of the late second century BCE found during the excavations of the theatre at Miletus. This is a calendar of the heliacal risings and settings of certain fixed stars in which a number of earlier authorities are mentioned; among these is Iv $\delta \omega \mathrm{v}$

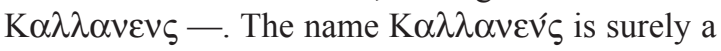
transliteration of the Sanskrit Kalyaña' or one of its Prākrit equivalents.
\end{abstract}

Although Pingree concludes by stating "even if $K \alpha \lambda \lambda \alpha v \varepsilon v$ vo was an Indian, he followed a Greek rather than an Indian tradition", the inscription does indicate to Greco-Indian exchanges at that early date.

Megesthenes has recorded in his work that cow's milk was used in India for the diseases of the eye. Homer has mentioned kassiteros, kastīra in Sanskrit, for tin. Dioscorides included Indian medicinal plants in his Materia Medica and wrote about their specific properties and application (Gunther, 1968, p. 2). ${ }^{28}$ These plants and their products were important items of trade between

\footnotetext{
${ }^{27}$ Spencer, 1935, writes a note on Erasistratus. 'Erasistratus of Ch'ios, fl. 3rd century B.C, one of the most celebrated anatomists and physicians of antiquity, lived at the court of Seleucus Nicator and later at Alexandria.'

${ }^{28}$ Dioscorides does not mention specific source of information like medical classics or physicians of the time. He just notes that he traveled extensively as a soldier and collected the knowledge himself.
} 
India and the ancient west. They formed ingredients in recipes listed by Celsus and others (Page et al., 1935, vol. II, p. 55). ${ }^{29}$ These incidents point to Greco-Indian exchanges with respect to science and scientific terminology. All in all, ancient contacts between Indians and Greeks, political and scientific, on the face of the aforesaid parallels in medical concepts suggest the possibility of exchanges in the field of medicine as well. Case of Erasistratus who was for a while a court physician of Seleucus Nicator and later a famous medical personality in Alexandria suggests the possibility of ancient Indian medical/surgical ideas reaching the ears of Alexandrian physiciansurgeons and vice versa. After all, it is possibly not as farfetched an idea as it would appear at first sight.

\section{Clifford Allbutt (1970, p.362) writes:}

Erasistratus in Alexandra laid stress on accurate diagnosis of disease and appreciation of individual 'diathesis' (Galen v.138). Though he concerned himself much with therapeutics he is not known to have written a special treatise on pharmacy; indeed, as we have seen (p. 154), he founded a new and alternative school of remedial treatment; a school of which Asclepiades was an ardent missionary in Rome, as was also Hikesius in Smyrna. Hikesius did write a book on diet and drugs which had considerable vogue, and took a place in the pharmaceutical tradition through Sextius, Pliny and onwards. Of the Erasistratean school as contrasted with the Herophilean, however, the main doctrine and practice lay rather in the sphere of physical methods - of diet, exercises, baths, massage, and so forth and but little in the pharmacy. Erasistratus indeed opposed the abuse of opium- "Succus papaveris" (Pliny, Natural History, XX 18), and scoffed at theriacs. It seems pretty certain that in scoffing at those physicians who mixed up together in their prescriptions metals, plants, matters taken from poisonous animals, and from under earth and sea, he was barking at his colleague Herophilus. No doubt the collections of Aristotle and the discoveries in India of Alexander the Great and his "scientific staff" found their way promptly to Alexandria".

This account supports the view that ideas related to ancient Indian medicine probably reached Alexandria in the period after Alexander's return. Medical experts like Erasistratus were skeptical and seem to have vehemently opposed some ideas, particularly propounded and practiced by Herophilus, those were conflicting to their medical and therapeutic philosophies. Again, it is interesting to note that it was the predecessors, especially Herophilus and his school ${ }^{30}$ (Klaus, 1989, p.575; von Staden, 1989, p.575) on whom Soranus was known to be dependent on while writing his works, as stated by Owsei Temkin and quoted earlier. Above narration connects Chandragupta to Seleucus Nicator and Megasthenes; further Seleucus Nicator to Erasistratus and Hirophilus. ${ }^{31}$ Again it connects Erasistratus to Alexandria and thereby Celsus. We see that in the above Pătaliputra-Alexandria route there is an undercurrent of medicine and surgery, both life-saving sciences very important to the above mentioned warring people.

\section{Concluding Remarks}

India and Greece had mutual contacts that go back to the fifth century BCE. These contacts intensified after Alexander's Asian conquest and during the Greek rule in the northwestern part of the Indian subcontinent for over three centuries starting from the late fourth century BCE. During this Greco-Bactrian period Indian and Greek cultures influenced each other in various fields

\footnotetext{
${ }^{29}$ In the recipes for antidotes Celsus includes Aloe, Costus or costmary, pepper and Indian nard. All of these are listed by Dioscorides as plants from India. See Gunther RT (1968), Aloe - Dioscorides Book III.25; Costus or costmary - Dioscorides Book I.15; Pepper - Dioscorides Book II.189; Indian nard - Dioscorides Book I.7

${ }^{30}$ Two entities that indicate to the possibility of Indian/Asian connections of Hellenistic science and medicine are scientific staff of Alexander the Great (which included his personal physicians viz. Critobulus or Critodemus of Cos and Draco, great grandson of Hippocrates) and the Asian branch of Herophilean school founded in the first century BCE.

31335 BCE- 280 BCE, lived mainly in Alexandria.
} 
including art, architecture, mythology, philosophy as well as science and technology, which are reflected in ancient literature, archeological finding $\mathrm{s}^{32}$ and even loan words in the Greek Materia Medica. Scholars have been aware of the possibility of exchanges in the field of medicine and surgery also.

Several Greek/Roman medical writers viz. Celsus, Soranus and Galen mention one Sostratus and his methods with respect to certain medical and surgical procedures which go close to Suśruta's procedures in respective topics. It appears that Sostratus was considered as a prominent surgeon of his time, which is inferred latest as the first century BCE. Considering Sostratus's fame as a surgeon, phonetic similarity to the Indian name Suśruta, their comparable period when there were constant contacts between the Mauryan and Greco-Bactrian kingdom, more importantly parallels in surgical techniques, and the fact that there is nothing attributed to Sostratus, the surgeon, which is not found in Suśrutasamhitā, following possibilities come up.

5.1 Similarities in surgical innovations of Suśruta and Sostratus are merely a coincidence and it is one example of parallel contemporary developments in different regions. Sostratus being less known as a surgeon in the ancient west and Wellman's comment that procedure of bringing the dead fetus at the mouth of mother's vagina and that of removing the stone both were innovations not often used in Greek medicine (Wellman, 1891 pp. 341) makes it less probable.

5.2 Sostratus was a practicing surgeon in Alexandria and Suśruta in Varanasi and through the Alexandria-Pâtaliputra connection information flowed in both directions. Now, Sostratus as a surgeon being unknown beyond a few medical writers/compilers makes this less likely. Sostratus's surgical practices being borrowed into Indian tradition and incorporated into then existing
Indian medical literature remains another option. If that were the case then it would have been a huge step which would have found mention in literature of succeeding centuries; just as Astronomical borrowings did in the form of Romaka and Pauliśasiddhānta. There are no such references to be found in Indian medical works.

5.3 Sostratus/Suśruta was a famous physician in Greco-Indian Empire in northwestern part of India and his contemporary Greek medical men and later Roman authors in the west knew and remembered the name for his innovative surgical procedures. He had connection with Banares and Pătaliputra, therefore his tradition continued in India and his surgical tradition remained as integral part of Sanskrit medical literature and in fact continued to develop for over two millennia (Deshpande, 2013, pp.175-205). All that is attributed to Sostratus as a surgeon is extant in Suśruta-samhitā. On the contrary, with time memory of Sostratus dwindled in the west.

Although accounts of Sostratus in a number of surgical fields narrated by ancient Roman medical writers come close to the corresponding accounts in Suśruta-samhitā, there is no mention of Sostratus in ophthalmic sections, although some of them, e.g. Celsus and Galen, have extensively discussed that topic. This corroborates with the traditional belief that the last chapter of SS, Uttaratantra, which contained ophthalmology, was added by Nāgārjuna and it is not attributed to the legendary Suśruta. The period of Nāgārjuna's revision is accepted as the first/second century CE and that is perhaps after Celsus wrote his De Re Medicina. Similarities in ophthalmic procedures described by Celsus and Suśruta suggest the possibility of ophthalmic exchanges between the two cultures as well. It is yet another interesting topic that is in the need of further research.

\footnotetext{
32 Pingree David, (1976) "Indian and Greek astronomical exchanges are found during the excavations of the theatre at Miletus."
} 


\section{ACKNOWLedgements}

I thank Professors Nathan Sivin and Geoffrey Lloyd for their scholarly advice in the writing of this paper; yet I am solely responsible for the conclusions made in the end.

\section{BIBLIOGRAPHY}

Aelian, On the Characteristics of Animals with an English translation by A F Scholfield, Cambridge, Mass., Harvard University Press London, Heinemann Press, 1958.

Arrian, Arrian with an English translation by P A Brunt and E. Iliff Robson, Mass Harvard University Press, Cambridge, 1976-78.

Bellamy, David and Pfister, Andrea. World Medicine Plants, Patients and People, Oxford \& Cambridge, UK, Blackwell, USA, 1992.

Burton, Gulik Charles. Deipnosophists/Athenaeus with English translation by C D Yonge, Vol. 1-7, Bohn H G publishers, London, 1853-54.

Charlesworth, M P. Trade routes and Commerce of the Roman Empire, Cambridge University Press, London, 1926, p.70.

Clifford, Allbutt T. Greek Medicine in Rome, Benjamin Blom Inc, 1970.

Cornello, A Celso. La Chirungia (Libri VII e VIII del De Medicina) Testo, traduzione commento; a cura di Innuocenzo Mazzini Macerata, Instituti Editoriali e Poligrafici Internazionali Pisa- Roma, 1999.

Deshpande, Vijaya. Ophthalmic Ideas in Ancient India, Indian Journal of History of Science, 48.2 (2013):175205.

Dickson, Keith. Stephanus the philosopher and physicianCommentary on Galen's Therapeutics to Glaucon, Brill, Leiden, Boston, Koln, 1998.

Flemming, Rebecca. Medicine and the Making of Roman Women, Oxford University Press, 2000.

Garrison, F H, An Introduction to History of Medicine, W B Saunders Company, Philadelphia and London, 1929.

Gilmore, John (ed.). The Fragments of the Persika of Ktesias, Macmillan \& Co, London and New York, 1888.

Grainger, John D. Seleucos Nikator: Constructing a Hellenistic Kingdom, Routledge, London and New York, 1990.
Grant, Michael. The Rise of the Greeks, Charles Scribner's sons, New York, 1988.

Greive, James. A Cornelius Celsus of Medicine in Eight Books, trans. with notes and critical and explanatory, Edinburgh University Press, London, 1814.

Gunther RT. The Greek Herbal of Dioscorides, Hafner Publishing Co, New York, 1968.

Jain, Ramachandra (ed). McCrindle's Ancient India as described by Megasthenes and Arrian, Today and Tomorrow's Printers and Publishers, New Delhi, 1972.

Jolly, Julius. Indian Medicine, trans. by C G Kashikar, Munshiram Manoharlal Publisher Pvt. Ltd, Delhi, 1977.

Karttunen, Klaus. India in early Greek literature, Finnish Oriental Society, Helsinki, 1989.

Karttunen, Klaus. Indian and the Hellenistic world, vol. 83 of Studia Orientalia, (ed.) by the Finnish Oriental Society, Helsinki, 1997.

Keay, John. India Discovered, New Delhi, Rupa \& Co., 1989.

Krumbhaar, E B (ed). History of Medicine by Castiglioni, Arturo, Alfred K. Knoff, New York, 1941.

Kuhn, C G. (ed \& tr). Claudii Galeni Opera Omnia, Georg Olms Heldesteim, 1965.

Kunjalal, Bhishgratna Kavirāj (ed), Suśruta Saṃhitā, Chaukhambha Sanskrit Series, Varanasi,1998.

Kutumbiah, P. Ancient Indian Medicine, Orient Longmans, Bombay, 1962.

McVaugh, Michael. Cataracts and Hernias: Aspects of Surgical Practice in the Fourteenth century, Med Hist, 45.3 (2001):319-340.

Majumdar, R C (ed). Ancient India as described by Megasthenes and Arrian by McCrindle J W, Chukerverthy, Chatterji and Co. Ltd., Calcutta. 1960.

Meulenbeld, G J. A History of Indian Medical Literature, Groningen Oriental Studies, Volume XV, Egbert Forsten, Groningen, 1999.

Nutton, Vivian. Galen on Theriac: Problems of Authenticity in Debru, Armelle, (ed.) Galen on Pharmacology, Philosophy and History and Medicine, Brill, Leiden, New York, Koln, 1997.

Page, T E; Capps E and Rouse W H D (ed). Celsus' De Medicina with English trans, by Spencer WA, Harvard University Press, Cambridge, Mass, 1935. 
Pandeya, Gangasahay (ed). Caraka Samhita, Chaukhambha, Banares, 1970.

Pauly, August; Wisdowa, George et al (ed). Real encyclopädie der classischen Altertumswissenschaft (Real Encyclopedia of Classical Antiquity), second series, Zweite Reihe, Vol 3 part 1 'Gossen on Sostratos' Sostratos (13) Wound surgeon (Celsius VII, 262, 23D) and zoologist, J B Metzler, Stuttgart, 18941980.

Pingree David, The Indian and pseudo-Indian Passages in Greek and Latin Astronomical and Astrological texts, Viator - Medieval and Renaissance Studies, VII (1976): 143.

Sastri, Kavirāj Ambika Datta (tr). Suśruta-saṃhitā written by Maharși Suśruta, Chaukhambha Sanskrit Samsthāna, Varanasi, 1953.
Sukh Dev, Ethnotherapeutics and Modern Drug Development: The potential of Ayurveda, Current Science, 73 .11(1997): 909.

Temkin, Owsei (tr). Soranus' Gynecology, Johns Hopkins Press, Baltimore, 1956.

von Staden Heinrich, Herophilus: The Art of Medicine in Early Alexandria, Cambridge University Press, Cambridge, 1989.

von Staden, Henrich. Celsus as Historian? in Ancient Histories of Medicine, ed. by Philip J Van Der Eijk, Brill, Leiden, Boston, Koln, 1999.

Wellmann, Max. Sostratos, ein Beitrag zur Quellenanalyse des Aelian (Sostratos, a Contribution to the Source Analysis of Aelian), Herme, 26.3(1891):321-350.

Zimmer, H R. Hindu Medicine, Johns Hopkins Press, Baltimore, 1948. 